\title{
USE OF S-INDEX AS A STRUCTURAL QUALITY INDICATOR FOR COMPACTED LATOSOLS CULTIVATED WITH MAIZE ${ }^{1}$
}

\author{
KARINA DE VARES ROSSETTI ${ }^{2 *}$, JOSÉ FREDERICO CENTURION ${ }^{3}$
}

\begin{abstract}
One way to prevent soil degradation is to monitor its structural quality through physical attributes and indicators. Thus, the objective of this work was to identify parameters that can be used together with the $S$-index to assess the soil structural quality of Latosols_-Distrophic Red Latosol (DRL) and Eutroferric Red Latosol (ERL) - cultivated with maize after traffic-induced compaction by agricultural machinery. The experiment was conducted in a randomized block design in split-plots, with five treatments and four replications for each soil class. The treatments were: $\mathrm{T} 0=$ conventional tillage without additional compaction; $\mathrm{T} 1, \mathrm{~T} 2$ and $\mathrm{T} 3=$ one pass of a 4, 7 and 10-Mg tractor, respectively; T4 = three passes of a $10-\mathrm{Mg}$ tractor. The water retention curve, density, porosity and $S$-index of the soil layers $0-0.1,0.1-0.2$ and $0.2-0.3 \mathrm{~m}$ were evaluated. The DRL presented similar $S$-index ( 0.035 to 0.037$)$ in the T0, T1 and T2, and these $S$-index were connected to soil macroporosity. Most $S$-index of the ERL were above 0.035 , except for T4 due to its higher soil density. The $S$-index can be used as a complementary parameter for maize height and soil macroporosity to evaluate the structural quality of DRL.
\end{abstract}

Keywords: Agricultural machinery traffic. Soil management. Soil physical-water attributes.

\section{ÍNDICE S COMO INDICADOR DA QUALIDADE ESTRUTURAL EM LATOSSOLOS COMPACTADOS CULTIVADOS COM MILHO}

\begin{abstract}
RESUMO - Uma maneira de prevenir a degradação do solo é monitorar a sua qualidade estrutural por meio de atributos e indicadores físicos. Dessa forma, objetivou-se com este trabalho verificar quais parâmetros podem ser utilizados junto com o índice $\mathrm{S}$ para a avaliação da qualidade estrutural do solo, após a compactação induzida por tráfego de máquinas agrícolas em um Latossolo Vermelho Distrófico (LVd) e em um Latossolo Vermelho Eutroférrico (LVef), cultivados com milho. O experimento foi conduzido em delineamento de blocos casualizados em parcelas subdivididas, com cinco tratamentos e quatro repetições, para cada classe de solo. Os tratamentos foram: $\mathrm{T} 0=$ preparo convencional sem compactação adicional; $\mathrm{T} 1, \mathrm{~T} 2$ e $\mathrm{T} 3=$ uma passada do trator de 4, 7 e 10 t, respectivamente; T4= três passadas do trator de 10 t. Foram avaliadas nas camadas de 0-0,10; 0,10-0,20 e 0,20-0,30 m a curva de retenção de água, a densidade, a porosidade do solo e o índice S. Os valores do índice $\mathrm{S}$ no LVd foram semelhantes $(0,035$ a 0,037$)$ no T0, T1 e T2, os quais estiveram relacionados à macroporosidade do solo. Para o LVef, a maioria dos valores do índice S situaram-se acima de 0,035, com exceção do T4, devido aos maiores valores de densidade do solo nesse tratamento. O índice $\mathrm{S}$ pode ser utilizado como um parâmetro complementar a altura do milho e a macroporosidade do solo, para a avaliação da qualidade estrutural em LVd.
\end{abstract}

Palavras-chave: Tráfego de máquinas agrícolas. Manejo do solo. Atributos físico-hídricos do solo.

\footnotetext{
${ }^{*}$ Corresponding author

${ }^{1}$ Received for publication in $09 / 02 / 2016$; accepted in $05 / 30 / 2017$.

Paper extracted from the doctoral thesis of the first author.

${ }^{2}$ Universidade do Estado de Mato Grosso, Pontes e Lacerda, MT, Brazil; krossetti@bol.com.br.

${ }^{3}$ Department of Soils and Fertilizers, Universidade Estadual Paulista, Jaboticabal, SP, Brazil; jfcentur@fcav.unesp.br.
} 


\section{INTRODUCTION}

The increase in agricultural mechanization and machinery operating capacity, and inadequate traffic intensity can cause damage to soil structure and plant growth. Compaction is one of the main causes of degradation of agricultural soils intensively and improperly managed, decreasing their productive capacity. The compaction of the soil increases soil density, reduces its aeration capacity and permeability to air and water, and mechanical resistance to the root system development. Therefore, the structural quality of the soil is essential to maintain the sustainability of agricultural systems.

The $S$-index developed by Dexter (2004) has been used to monitor soil quality. This index is calculated from the soil water retention curve (WRC), expressed by the structural porosity resulted from micro-slits, cracks, bio-pores and macro-structural pores that are formed due to the soil use and management for crops. The $S$-index makes it possible to identify the highest slope of the WRC. The higher this index, the better the pore distribution and size. According to Dexter (2004), the limit between good and poor structural quality of soils of Poland and England is approximately 0.035 . $S$-index $<0.020$ with clay content of 40 to $730 \mathrm{~g} \mathrm{~kg}^{-1}$ indicates predominance of textural porosity, which is connected with poor soil physical conditions. However, these values do not refer to tropical soils. There is a great variation in the size of macro and micropores, so the pore space of the soil can be evaluated considering the bimodal distribution, with pores classified as inter- and intra-aggregated, representing structural and textural porosity, respectively. Structural pores are responsible for shelter living organisms, thus, they are essential for decomposition and cycling of organic materials in the soil. Moreover, structural pores improve the aeration for roots, and conduct and drain water in the soil, and textured pores increase water retention and availability (DEXTER et al., 2008).

In the Cerrado biome in the Center-West and Northeast regions of Brazil, the $S$-index of 0.045 is an adequate limit between soils of good structural quality and those that tend to became degraded; and $S$-index $\leq 0.025$ indicated soils entirely physically degraded. (ANDRADE; STONE, 2009).

According to Cunha et al. (2011), the $S$-index was adequate as indicator of the physical quality of a Distrophic Red Latosol under conventional and no-tillage system, with a significant and negative correlation of $S$-index with soil density and microporosity, and positive correlation of macroporosity with total porosity and soil organic matter content. According to Rossetti, Centurion and Sousa Neto (2013), the $S$-index should not be recommended as a singly indicator of soil physical quality. This was also reported by Lier (2014), who explains that the estimate of soil quality based on
$S$-index is questionable.

In this context, the objective of this work was to identify parameters that can be used together with the $S$-index to assess the soil structural quality of Latosols-Distrophic Red Latosol (DRL) and Eutroferric Red Latosol (ERL)—cultivated with maize after traffic-induced compaction by agricultural machinery.

\section{MATERIAL AND METHODS}

The experiment was conducted in Jaboticabal SP, Brazil $\left(21^{\circ} 14^{\prime} 05^{\prime \prime} \mathrm{S}, 48^{\circ} 17^{\prime} 09^{\prime \prime} \mathrm{W}\right.$ and altitude of $615 \mathrm{~m})$. The climate of this region, according to the classification of Köppen, is Cwa, with hot summer and dry winter. The region has average annual precipitation of $1.428 \mathrm{~mm}$ and annual average temperature of $21^{\circ} \mathrm{C}$.

The two soils were classified according to Santos et al. (2013). The first as typical kaolinitic hipoferric Distrophic Red Latosol of medium texture, moderate A horizon, and source material derived mainly from sandstones of the Bauru Group in its highest and flat portions, with $348 \mathrm{~g} \mathrm{~kg}^{-1}$ of clay, $598 \mathrm{~g} \mathrm{~kg}^{-1}$ of sand, $54 \mathrm{~g} \mathrm{~kg}^{-1}$ of silt, and density of 2.89 in the layer $0.0-0.2 \mathrm{~m}$ (DRL); and the second as typical kaolinitic oxidic Eutroferric Red Latosol of clayey texture, moderate A horizon, and source material derived mainly from altered products of basalts (Serra Geral Formation) underlying the sandstones, with $560 \mathrm{~g} \mathrm{~kg}^{-1}$ of clay, $240 \mathrm{~g} \mathrm{~kg}^{-1}$ of sand, $200 \mathrm{~g} \mathrm{~kg}^{-1}$ of silt, and density of $2.74 \mathrm{Mg} \mathrm{m}^{-3}$ in the layer $0.0-0.2 \mathrm{~m}$ (ERL). A conventional tillage (depth of $0.30 \mathrm{~m}$ ) followed by a leveling harrowing was carried out before the experiment implementation.

The experiment was conducted in a randomized blocks design in split-plot with five treatments and four replications for each soil class. The treatments were: $\mathrm{T} 0=$ conventional tillage without additional compaction; $\mathrm{T} 1, \mathrm{~T} 2$ and $\mathrm{T} 3=$ one pass of a 4,7 and $10-\mathrm{Mg}$ tractor, respectively; $\mathrm{T} 4=$ three passes of a $10-\mathrm{Mg}$ tractor. Each passing of the tractor for soil compaction consisted of passing the wheels of the tractor over the whole surface of the plot. A native forest area (NFA) was used as control treatment to evaluate the soil physical attributes of the DRL and ERL. The subplots consisted of the soil layers: $0.0-0.1$; $0.1-0.2$ and $0.2-0.3 \mathrm{~m}$. The treatments were implemented in November 2012, when the soil water content was close to the field capacity in the layer 0.0-0.2 m (EMBRAPA, 2011).

The tractor used for T1 had a 56-kW (70-hp) motor, front tire (R1) pressure of $83 \mathrm{kPa}$ and rear tire (R1 18.4-30) pressure of $96 \mathrm{kPa}$, traction $4 \times 2$, and weight of $4 \mathrm{Mg}-30 \%$ in the front and $70 \%$ in the rear wheels. The tractor used for $\mathrm{T} 2$ had a $77-\mathrm{kW}$ (105-hp) motor, 4x2 traction with auxiliary front 
wheel drive, and weight of $7 \mathrm{Mg}-40 \%$ in the front and $60 \%$ in the rear wheels. The tractor used for T3 and T4 had a 105-kW (143-hp) motor, 4x4 traction, radial (L-3) tires (17.5 R25), a front loader, and weight of $10 \mathrm{Mg}$ with the empty loader. These tractors were operated at speed $\leq 5 \mathrm{~km} \mathrm{~h}^{-1}$, with tires calibrated and in good conditions.

Maize sowing was carried out in December, 2012, using the simple hybrid Maximus, using a no-till seed cum fertilizer drill with five rows spaced $0.90 \mathrm{~m}$ apart. The experimental plots consisted of five 6-m sowing rows and the 3 central meters of the three central rows were used for evaluation.

Chemical analysis was performed in the soil layer 0.0-0.20 m (VAN RAIJ et al., 2001) (Table 1). The sowing fertilization consisted of $340 \mathrm{~kg} \mathrm{ha}^{-1}$ of the formulation 8-28-16 (N-P-K), aiming a maize yield of 6 to $8 \mathrm{Mg} \mathrm{ha}^{-1}$. Side-dressing was performed at the V6 stage of the crop with $250 \mathrm{~kg} \mathrm{ha}^{-1}$ of the formulation 20-0-20 (N-P-K), with the same seed cum fertilizer drill used in sowing. Cultural practices were carried out with the same tractor used in $\mathrm{T} 2$, with soil water content close to the field capacity.

Table 1. Chemical characteristics of the Dystrophic Red Latosol (DRL) and Eutroferric Red Latosol (ERL) in the layer 0.0-0.20 $\mathrm{m}$ before the experiment.

\begin{tabular}{|c|c|c|c|c|c|c|c|c|c|c|c|}
\hline \multirow[t]{2}{*}{ Soil } & \multirow{2}{*}{$\underset{\mathrm{CaCl}_{2}}{\mathrm{pH}}$} & \multicolumn{2}{|c|}{--------OM--------- } & \multirow[t]{2}{*}{ P-resin } & \multirow[t]{2}{*}{$\mathrm{K}^{+}$} & \multirow[t]{2}{*}{$\mathrm{Ca}^{2+}$} & \multirow[t]{2}{*}{$\mathrm{Mg}^{2+}$} & \multirow[t]{2}{*}{$\mathrm{H}+\mathrm{Al}$} & \multirow[t]{2}{*}{ SB } & \multirow[t]{2}{*}{$\mathrm{CEC}$} & \multirow[t]{2}{*}{$\bar{V}$} \\
\hline & & Maize & NFA & & & & & & & & \\
\hline & & $------g d$ & - & $\mathrm{mg} \mathrm{dm}^{-3}$ & & & --- & $\mathrm{lc} \mathrm{dm}$ & & - & $\%$ \\
\hline DRL & 5.6 & 16 & 30 & 40 & 2.0 & 21 & 17 & 20 & 40 & 60 & 67 \\
\hline ERL & 4.9 & 24 & 55 & 61 & 2.7 & 30 & 12 & 27 & 45 & 72 & 62 \\
\hline
\end{tabular}

OM: soil organic matter; SB: sum of bases; CEC: cation exchange capacity; V: base saturation; NFA: native forest area; Maize: area under conventional tillage and soil compaction.

The soil physical attributes of each plot were determined in January, 2013, using 120 undisturbed samples of soil collected from between the maize rows with cylinders of $53.1810^{-6} \mathrm{~m}^{3}(0.032 \mathrm{~m}$ high and $0.046 \mathrm{~m}$ diameter); and 24 undisturbed samples from the NFA. The samples were saturated and subjected to tensions of $0.001,0.003,0.006,0.01$, $0.033,0.06,0.1$ and $0.3 \mathrm{MPa}$ in Richards' chambers (DANE; HOPMANS, 2002). They were then weighed, and dried in an oven at $105^{\circ} \mathrm{C}$ for $24 \mathrm{~h}$ to determine their water content at each tension, and density (GROSSMAN; REINSCH, 2002). Microporosity was determined by drying at a tension of $0.01 \mathrm{MPa}$ and macroporosity by the difference between total porosity and microporosity (FLINT; FLINT, 2002). The tension of $1.5 \mathrm{MPa}$ was evaluated by a WP4-T Dewpoint Potential Meter thermocouple psychrometer.

The results were then fitted to the soil water retention curve (VAN GENUCHTEN, 1980) using the Soil Water Retention Curve (SWRC) program (DOURADO NETO et al., 2001). the $S$-index, tangent to the soil water curve at the inflection point, was determined based on the parameters obtained (DEXTER, 2004).

After the grain physiological maturity, the plant height - soil surface to the point of inflection of the flag leaf - and grain weight were evaluated in 10 plants per plot. Maize grain yield was presented in $\mathrm{Mg} \mathrm{ha}^{-1}$, with grain moisture corrected to $13 \%$.

The results were then subjected to analysis of variance using the software Assistat 7.7 beta; and significant means were compared by the Tukey's test $(p<0.05)$. Linear regression analyzes were conducted to assess the correlation of the $S$-index with soil density, macroporosity, and plant height. The $S$-index can not be used singly; thus, the soil and maize parameters that can be used together with this index to evaluate the soil structural quality were identified. The $S$-index and other soil and plant parameters were also evaluated through multiple regression using the software Statistica 7.0.

\section{RESULTS AND DISCUSSION}

The tractor traffic changed the soil density (SD), with greater intensity in the subsurface layers (0.1-0.2 and $0.2-0.3 \mathrm{~m})$. Increases in compaction from the layer $0.0-0.1 \mathrm{~m}$ were observed in $\mathrm{T} 1$ (one pass of a 4-Mg tractor), T3 (one pass of a $10-\mathrm{Mg}$ tractor) and $\mathrm{T} 4$ (three passes of a $10-\mathrm{Mg}$ tractor) in the DRL; and in T0 (conventional tillage, without additional traffic), $\mathrm{T} 1, \mathrm{~T} 2$ (one pass of a $7-\mathrm{Mg}$ tractor) and T3 in the ERL (Table 2). Thus, the previous use of a leveling harrow after soil scarification may have favored the formation of physical barriers below the soil layers affected by the implements. The subsurface layer continued to compact with increasing tractor traffic. The difference in the compaction of the soils was due to the lower density of the ERL $\left(2.74 \mathrm{Mg} \mathrm{m}^{-3}\right)$ compared with the DRL $\left(2.89 \mathrm{Mg} \mathrm{m}^{-3}\right)$. This result confirm that found by Reichert et al. (2009) through analysis in a literature database: the critical soil density decrease with increasing clay content. Therefore, the SD of the native forest area (NFA) were lower in all layers compared to all treatments with soil management in both soils. The 
susceptibility to compaction in the natural environment (NFA) is smaller compared to crop areas due to its high organic matter (OM) (Table 1). The presence of OM in the soil results in dissipation of part of the applied energy by the tractor.
Moreover, the plant diversity in areas with natural vegetation is usually high, with a consequent high diversity of other living organisms in the soil, which contributes to the development of pores and reduce the density of the soil.

Table 2. Density, macroporosity and microporosity of different layers of a Distrophic Red Latosol (DRL) and an Eutroferric Red Latosol (ERL) subjected to different traffic intensities, and under Native Forest.

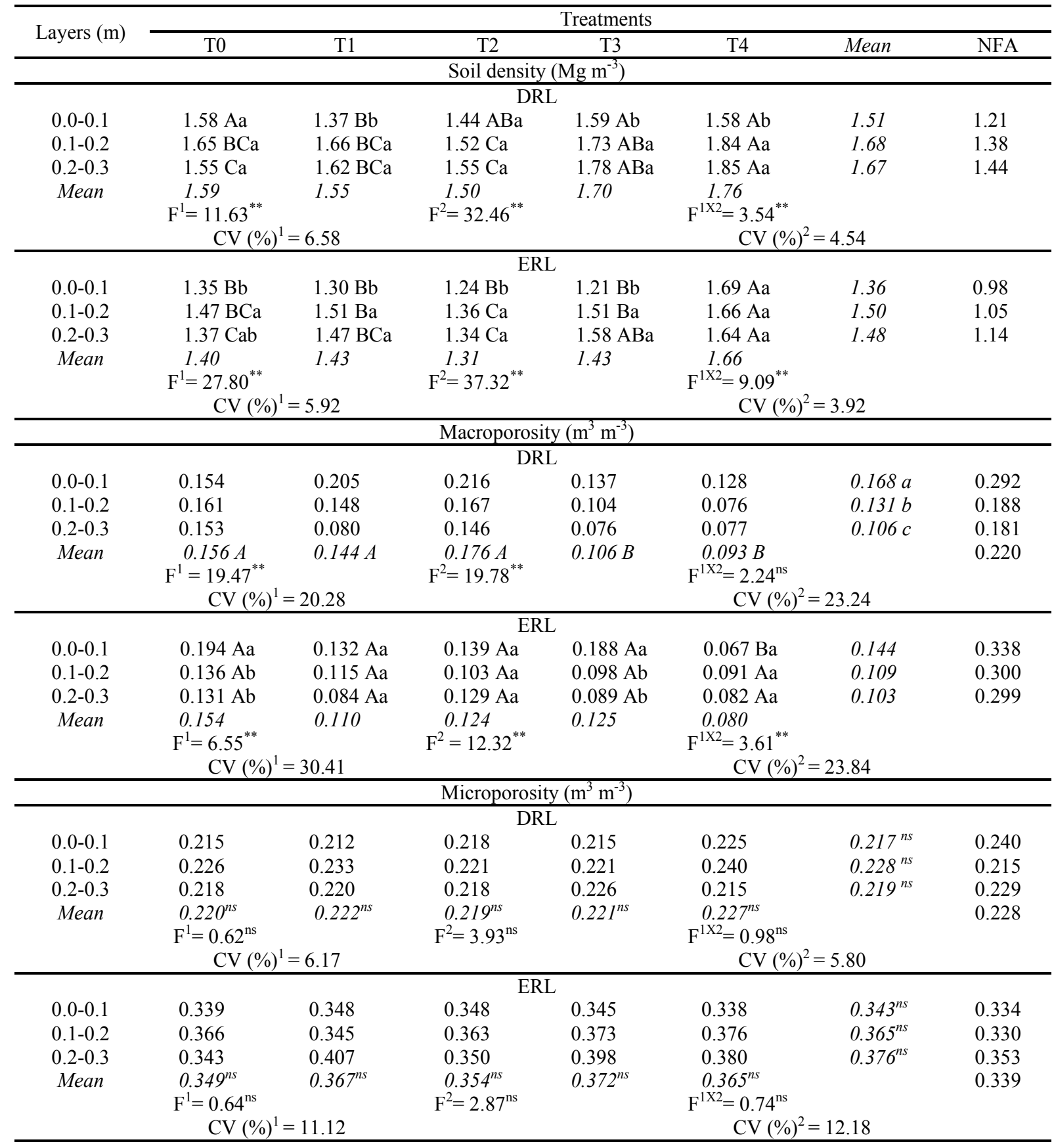

$\mathrm{T} 0=$ conventional tillage without additional compaction; $\mathrm{T} 1, \mathrm{~T} 2$ and $\mathrm{T} 3=$ one pass of a 4,7 and $10-\mathrm{Mg}$ tractor, respectively; T4 $=$ three passes of a 10-Mg tractor. NFA: native forest area. (1) Coefficient of variation referring to the treatments (plots). (2) Coefficient of variation referring to the layers (subplots). Means followed by the same letter do not differ by the Tukey's test $(p<0.05)$; uppercase letters compare treatments in the rows, and lowercase letters compare layers of the same treatment in the columns, uppercase italics letters compare averages of treatments and lowercase italics letters compare averages of layers; $\mathrm{Ns}=$ not significant; and $* *=$ significant $(p<0.01)$. 
Bergamin et al. (2010) found an increase in $\mathrm{SD}$ in the layer $0.0-0.1 \mathrm{~m}$ of a clayey dystrophic Red Latosol after two passes of a $5-\mathrm{Mg}$ tractor in a no-tillage area, with no increases in SD after increasing the number of passes to four and six. The additional compactions presented increases in SD in the surface layer from T3 in the DRL, and T4 in the ERL. This result can be attributed to the organic matter and clay content in the ERL, which more efficiently resisted to the traffic intensity with the $10-\mathrm{Mg}$ tractor than the DRL.

The similar SD between T0 and most treatments with additional compaction in the surface layer of both soils may be explained by the soil sampling time, which occurred one month and 10 days after sowing. The changes in the SD of the ERL due to machinery traffic (T4) resulted in a reduction of $34.5 \%$ in the macroporosity in the layer $0.0-0.1 \mathrm{~m}$. In the layers $0.1-0.2$ and $0.2-0.3 \mathrm{~m}$, the volume of macropores in the ERL of the treatments was similar, regardless of the number of passes and weight of the tractors. Servadio et al. (2005) found different results, with decreasing macroporosity in these layers with the tractor passes compared to areas without traffic.

The results found for the ERL confirm that reported by Freddi et al. (2009), that the traffic of tractors modifies the macroporosity only in the surface layer $(0-0.20 \mathrm{~m})$. The macroporosity of the ERL was lower than $0.10 \mathrm{~m}^{3} \mathrm{~m}^{-3}$ in the layer $0.2-0.3 \mathrm{~m}$ in $\mathrm{T} 1 \quad\left(0.084 \mathrm{~m}^{3} \mathrm{~m}^{-3}\right)$, in the layer $0.10-0.30 \mathrm{~m}$ in $\mathrm{T} 3\left(0.098\right.$ and $\left.0.089 \mathrm{~m}^{3} \mathrm{~m}^{-3}\right)$ and in all layers in T4 $\left(0.067,0.091\right.$ and $\left.0.082 \mathrm{~m}^{3} \mathrm{~m}^{-3}\right)$. These results indicate a probable limitation to aeration of the soil, even in wetter seasons. The macroporosity in the the layers $0.0-0.1,0.1-0.2$ and 0.2-0.3 $\mathrm{m}$ of the treatments with soil management (Table 2) decreased compared with the NFA, both in the DRL $\left(0.124,0.057\right.$ and $0.075 \mathrm{~m}^{3} \mathrm{~m}^{-3}$, respectively; $\mathrm{OM}=30 \mathrm{~g} \mathrm{dm}^{-3}$ ) and in the ERL $\left(0.194,0.191\right.$ and $0.196 \mathrm{~m}^{3} \mathrm{~m}^{-3}$, respectively; $\mathrm{OM}=55 \mathrm{~g} \mathrm{dm}^{-3}$ ). The OM in the DRL of the NFA was different from that in the treatments with soil management. The reduction of the macroporosity in these treatments was probably also due to the soil compaction by the tractors.

There was no interaction of the treatments and layers with microporosity in the ERL, nor of macroporosity and microporosity in DRL (Table 3 ). The DRL in T3 and T4 had the lowest values of macroporosity, compared with the other treatments, with a decrease in subsurface. The microporosity of both soils was not sensitive to the changes caused by the traffic of the tractors nor to the conventional tillage. This result can be explained by the strong correlation of the soil microporosity with soil texture and organic matter content, and week correlation with the increase of SD originated from the machinery traffic.

The highest water retention in DRL in the treatments with soil management were found in $\mathrm{T} 2$ and T1 $(0.0-0.1 \mathrm{~m}), \mathrm{T} 0(0.1-0.2 \mathrm{~m})$ and $\mathrm{T} 0$ and $\mathrm{T} 2$ (0.2-0.3 m), at tensions of $0.01 \mathrm{MPa}$ (Figure 1). The water retention curve (WRC) in ERL was higher in T1 (0.0-0.1 and 0.2-0.3 m) and T3 (0.1-0.2 m). Thus, the WRC followed the trend DRL $<$ ERL, and are directly related to the OM content (Table 1), which determine changes in pore quantity and distribution. The higher WRC at low tensions for the oxidic ERL compared with the kaolinite DRL is mainly due to the oxidic mineralogy of the clay fraction, which promotes the formation of rounded microaggregates of less than $1 \mathrm{~mm}$, higher proportion of large pores, and lower SD. Conversely, Betioli Júnior et al. (2012) found a positive relationship between WRC and SD in a Red Latosol managed over 30 years under no-tillage.

The treatments $\mathrm{T} 0, \mathrm{~T} 1$ and $\mathrm{T} 2$ presented similar $S$-index values $(0.035$ to 0.037$)$ in the DRL (Table 3). The increase in the weight of the tractor to $10 \mathrm{Mg}$ in T3 reduce the $S$-index to 0.016 in DRL. According to Freddi et al. (2009) a 4-Mg tractor pass (light and small tractor) reduced the $S$-index to 0.035 in the layers $0.0-0.1$ and $0.1-0.2 \mathrm{~m}$ of a DRL. When three passes of the $10-\mathrm{Mg}$ tractor (T4) was used in the DRL, the $S$-index did not changed. Therefore, the reduction of $S$-index with T3 and T4 in the DRL may be connected to the decrease of the peak of pore frequency distribution, resulting in a vertical flattening of the WRC by the reduction of the structural pores (DEXTER, 2004). Moreover, a $S$-index $<0.020$ indicates extremely degraded physical structure (DEXTER, 2004). The results of the $S$-index in the treatments and layers evaluated encompasses the macroporosity of this soil.

Mean $S$-index close to 0.020 were also found by Cavalieri et al. (2011) in a Red Latosol of medium texture up to $0.40 \mathrm{~m}$ depth after mechanized harvest of sugarcane. Souza (2012) found a higher $S$-index (0.048) in a clayey Dystroferric Red Latosol subjected to traffic of a $6.8-\mathrm{Mg}$ tractor-similar results were found in $\mathrm{T} 0$ and $\mathrm{T} 2$ in the ERL evaluated in this study-however, their $S$-index for three and six passes were 0.032 and 0.029 , respectively.

Most $S$-index in ERL were above 0.035 , except in T4 $(0.026)$ due to the high SD in the layers $0.0-0.1$ and $0.1-0.2 \mathrm{~m}$. The $S$-index of T0 (conventional tillage) in ERL was similar to those of the treatments that received a lower weight of compaction (T1 and T2), and T3. The $S$-index in the T0 and T2 of the ERL were above 0.045 , which is considered the most suitable limit for tropical soils (ANDRADE; STONE, 2009). The $S$-index of the ERL showed no significant differences, and significant differences in SD, between layers. 

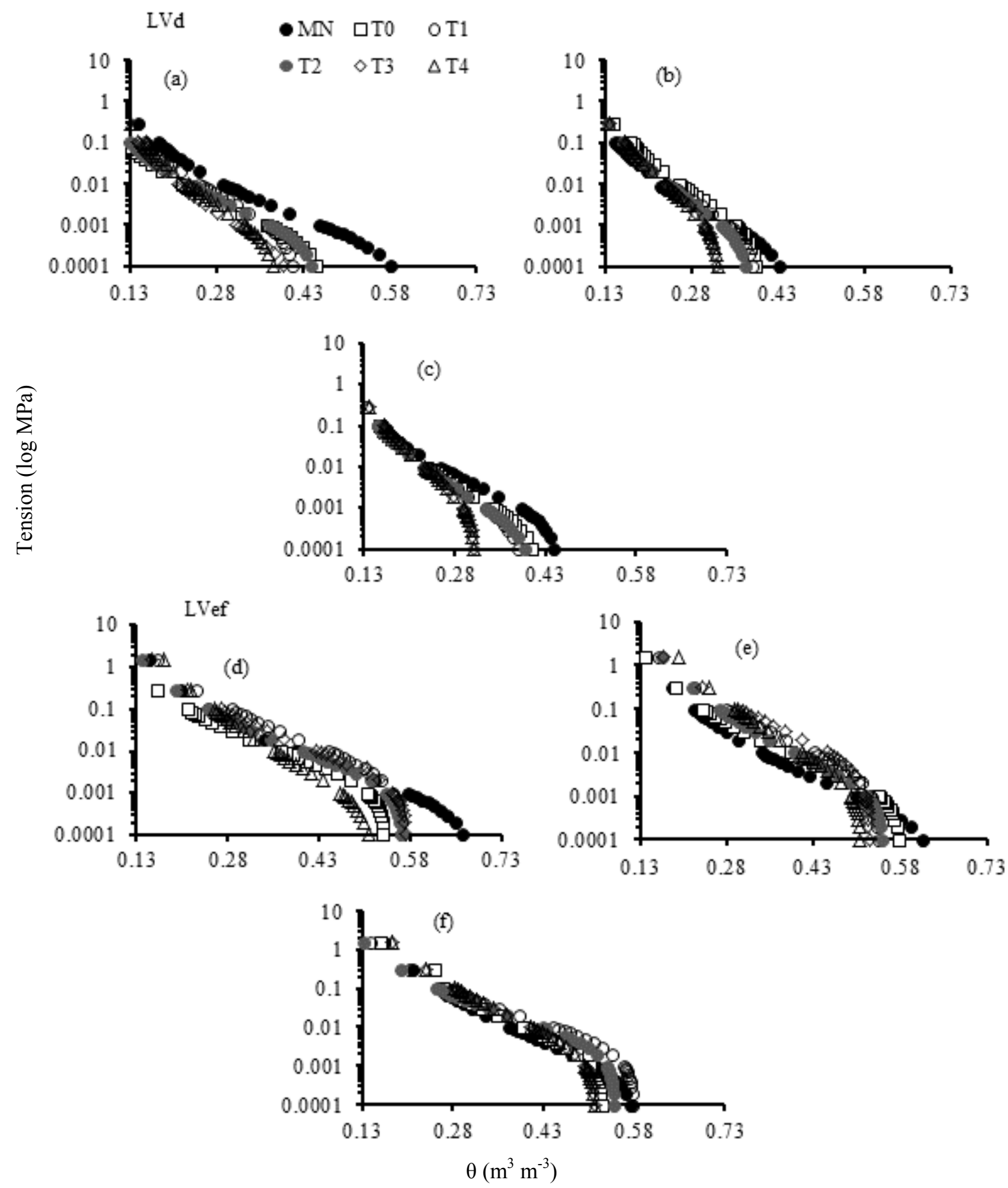

Figure 1. Water retention curves in the layers $0.0-0.1 \mathrm{~m}(\mathrm{a}), 0.1-0.2 \mathrm{~m}$ (b) and $0.2-0.3 \mathrm{~m}$ (c) of a Red Dystrophic Latosol (DRL), and in the layers $0.0-0.1 \mathrm{~m}(\mathrm{~d}), 0.1-0.2 \mathrm{~m}$ (e) and $0.2-0.3 \mathrm{~m}$ (f) of an Eutroferric Red Latosol (ERL). $\mathrm{T} 0=$ conventional tillage without additional compaction; $\mathrm{T} 1, \mathrm{~T} 2$ and $\mathrm{T} 3=$ one pass of a 4,7 and $10-\mathrm{Mg}$ tractor, respectively; $\mathrm{T} 4=$ three passes of a $10-\mathrm{Mg}$ tractor; $\mathrm{NFA}=$ native forest area.

The highest $S$-index were found in the native forest, both in DRL (0.059) and ERL (0.071). Thus, the area without anthropic action had better physical quality than the managed areas. According to Araújo (2014), a native forest also presented a higher $S$-index (0.121 to 0.125$)$ in a Ultisol when compared to cultivated areas. This author attributed this result to a better pore configuration, which cause less physical restriction for root growth related to aeration, mechanical restriction and water retention. Guedes et al. (2012) confirmed that high $S$-index was obtained in forest area of Yellow Latosol, regardless of the layers evaluated. Moreover, Cunha et al. (2012) also found a structural quality of soil under native forest superior to the cultivated soil. 
Table 3. $S$-index in different layers of a Dystrophic Red Latosol (DRL) and an Eutroferric Red Latosol (ERL) subjected to different traffic intensities, and under native forest.

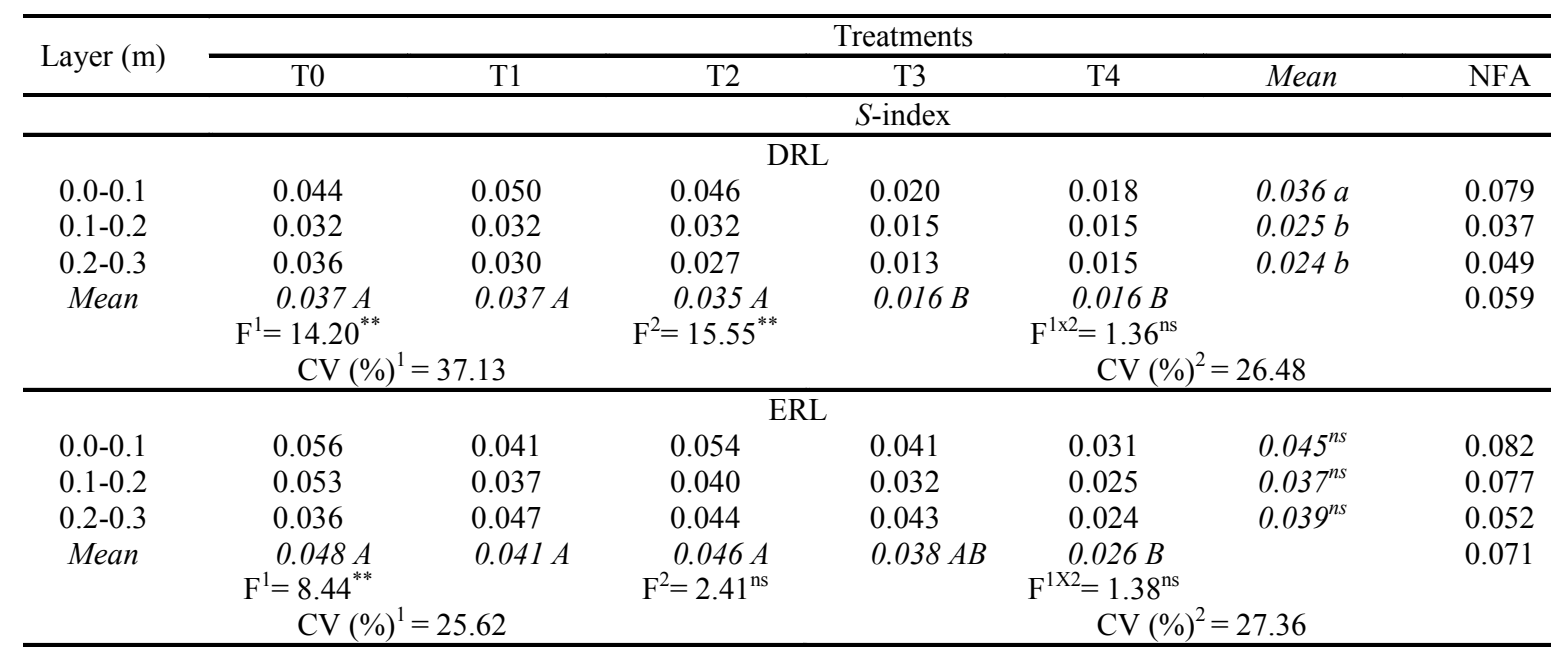

$\mathrm{T} 0$ = conventional tillage without additional compaction; $\mathrm{T} 1, \mathrm{~T} 2$ and $\mathrm{T} 3=$ one pass of a 4,7 and $10-\mathrm{Mg}$ tractor, respectively; $\mathrm{T} 4=$ three passes of a $10-\mathrm{Mg}$ tractor. NFA: native forest area. (1) Coefficient of variation referring to the treatments (plots). (2) Coefficient of variation referring to the layers (subplots). Means followed by the same letter do not differ by the Tukey's test $(p<0.05)$; uppercase letters compare treatments in the rows, and lowercase letters compare layers of the same treatment in the columns, uppercase italics letters compare averages of treatments and lowercase italics letters compare averages of layers; $\mathrm{Ns}=$ not significant; $* *=$ significant $(\mathrm{p}<0.01)$.

The mean $S$-index of the three layers of the cultivated soils (0.0-0.1, 0.1-0.2 and 0.2-0.3 m) was significantly correlated with their SD, macroporosity and maize height in both soils (Figures 2 and 3). However, the regression with maize yield was not significant (in DRL $=0.8727+522.82-8686.8 \mathrm{~S}^{2}$, $\mathrm{R}^{2}=0.59^{\text {ns }} ;$ and in ERL $=2.3268+102.31 \mathrm{~S}$, $\mathrm{R} 2=0.67^{\mathrm{ns}}$ and $\mathrm{r}=0.82^{\mathrm{ns}}$ ). The regressions of SD with $S$-index and macroporosity with $S$-index fitted to the linear model, with negative and positive correlation, respectively. Similar results (SD with $S$-index, $\mathrm{r}=-0.96, \mathrm{p}=0.01$; and $S$-index with macroporosity, $\mathrm{r}=0.96, p=0.01$ ) were obtained by Cunha et al. (2011) evaluating the $S$-index of a acriferric Red Latosol under different uses and managements (conventional, years of no-till, and native forest).

Negative regression of SD with $S$-index $(\mathrm{r}=-0.75$ and $\mathrm{p}<0.01)$ was also reported by Silva et al. (2012) in a clayey DRL, confirming the results found in this study. These authors emphasized the sensitivity of this index to soil structural change, even though it is very small, and concluded that the $S$-index is a good tool for monitoring soil physical quality. Yang et al. (2015) also showed a negative linear correlation between S-index and SD (1.35 to $1.55 \mathrm{Mg} \mathrm{m}^{-3}$ ) in soil samples (150 to $350 \mathrm{~g} \mathrm{~kg}^{-1}$ clay) collected in northern China, but with low $\mathrm{R}^{2}(0.02)$, which may indicate a lack of correlation between these parameters; and the SD was considered less important than the clay content.

Considering the limit $S$-index of
Dexter (2004) $(S$-index $=0.035)$ for soils with good structural quality, the limit values were based on the regression equation in Figure 2, with $\mathrm{SD}=1.59$ (DRL) and 1.54 (ERL) $\mathrm{Mg} \mathrm{m}^{-3}$, and macroporosity $=0.156$ (DRL) and $0.099\left(\right.$ ERL) $\mathrm{m}^{3} \mathrm{~m}^{-3}$. The limit $S$-index proposed was similar to the minimum condition of macroporosity for the growth and development of the maize roots in the ERL.

According to Freddi et al. (2009), $S$-index below 0.035 promote significant decrease in maize yield under soils with tractor-induced compaction. However, a different limit value was found by Beutler et al. (2008), who observed that the maize yield decreased in conditions of intensive agricultural machinery traffic from $S$-index $=0.062$ in DRL. According to the estimated means of positive and significant regressions, the height of maize with $S$-index $=0.035$ in DRL $(2.01 \mathrm{~m})$ was higher than that in ERL $(1.60 \mathrm{~m})$ (Figure 3), even with higher values of SD, because of its predominant mineralogy, and higher sand content $\left(598 \mathrm{~g} \mathrm{~kg}^{-1}\right)$ and density $\left(2.89 \mathrm{Mg} \mathrm{m}^{-3}\right)$.

The T0 in the DRL presented the highest maize yield (Table 4), even though its SD was similar to some other treatments with tractor-induced compaction. This SD was due to the soil sampling period - 40 days after sowing. The results of T0 is attributed to the benefit of soil preparation and favorable meteorological conditions-rainfall during the crop cycle. 

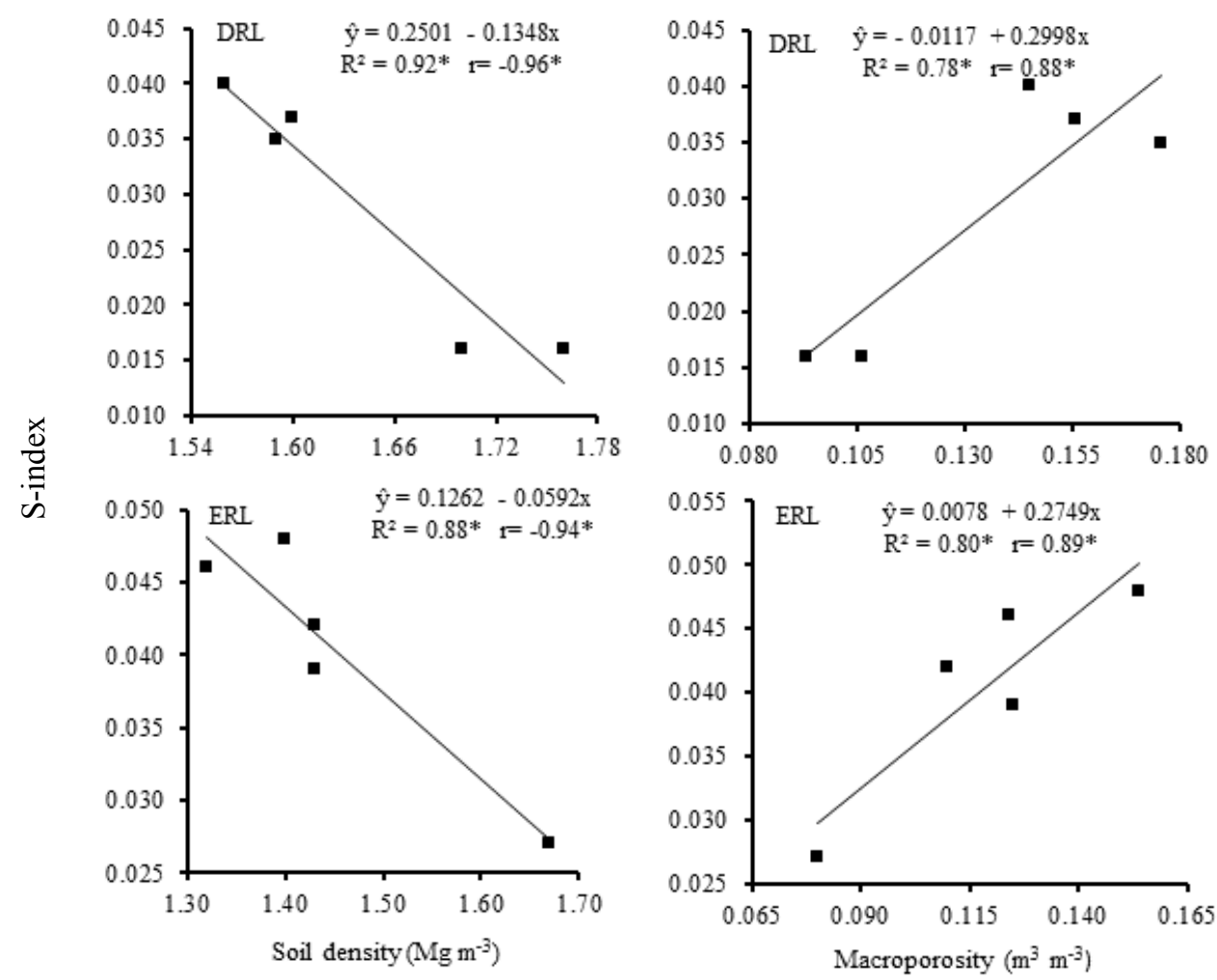

Figure 2. Regressions of physical quality indicators in Dystrophic Red Latosol (DRL) and Eutrophic Red Latosol (ERL): $S$-index, soil density and macroporosity. ${ }^{*}=$ Significant at $p<0.05$.
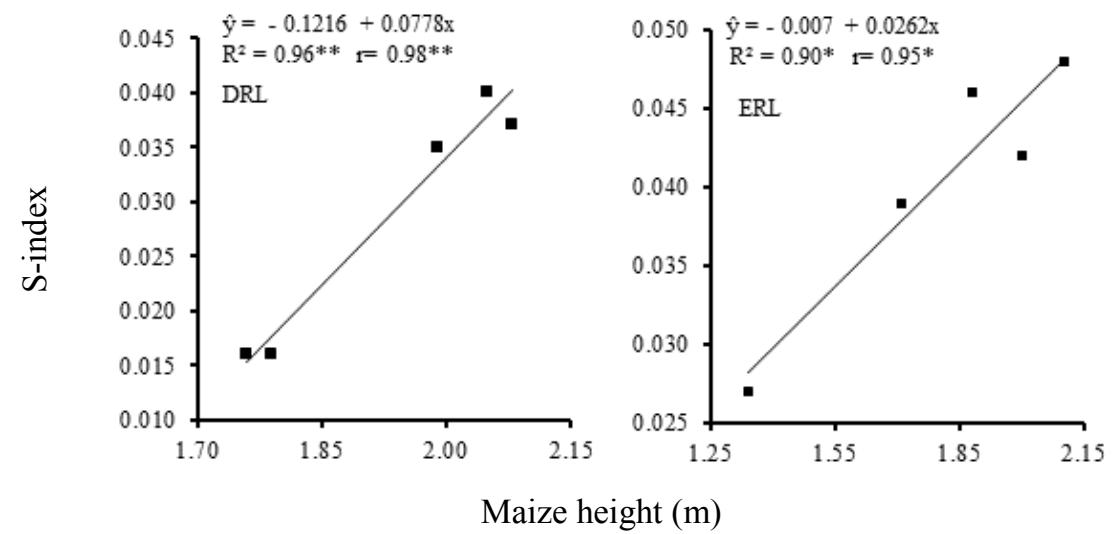

Figure 3. Regressions of physical quality indicators in Dystrophic Red Latosol (DRL) and in Eutrophic Red Latosol (ERL): $S$-index and height of maize plants. $*=$ significant at $p<0.05$, and $* *=p<0.01$.

Table 4. Maize yield and height in a Dystrophic Red Latosol (DRL) and an Eutroferric Red Latosol (ERL) subjected to different traffic intensities.

\begin{tabular}{ccccc}
\hline Treatment & Yield & Height & Yield & Height \\
\hline & Mg ha $^{-1}$ & $\mathrm{~m}$ & Mg ha $^{-1}$ & $\mathrm{~m}$ \\
T0 & DRL & & & ERL \\
T1 & $9.23 \mathrm{a}$ & $2.08 \mathrm{a}$ & $7.32 \mathrm{a}$ & $2.10 \mathrm{a}$ \\
T2 & $7.57 \mathrm{~b}$ & $2.05 \mathrm{a}$ & $7.50 \mathrm{a}$ & $2.00 \mathrm{ab}$ \\
T3 & $7.93 \mathrm{~b}$ & $1.99 \mathrm{a}$ & $6.69 \mathrm{ab}$ & $1.88 \mathrm{bc}$ \\
T4 & $6.76 \mathrm{~b}$ & $1.76 \mathrm{~b}$ & $5.62 \mathrm{~b}$ & $1.71 \mathrm{c}$ \\
F & $7.28 \mathrm{~b}$ & $1.79 \mathrm{~b}$ & $5.17 \mathrm{~b}$ & $1.34 \mathrm{~d}$ \\
$\mathrm{CV}(\%)$ & $11.18^{* *}$ & $21.00^{* *}$ & $8.29^{* *}$ & $51.67^{* *}$ \\
\hline
\end{tabular}

$\mathrm{T} 0$ = conventional tillage without additional compaction; $\mathrm{T} 1, \mathrm{~T} 2$ and $\mathrm{T} 3=$ one pass of a 4,7 and $10-\mathrm{Mg}$ tractor, respectively; T4 = three passes of a 10-Mg tractor. NFA: native forest area. Means followed by the same letter do not differ by the Tukey's test $(p<0.05)$; $* *=$ significant $(p<0.01)$. 
The maize yield in ERL decreased with the soil compaction in T3 and T4 when compared to the T0 and T1. In DRL, the different induced soil compaction did not affected maize yield. The absolute maize yield in ERL was higher than in DRL due to its higher OM (Table 1) and clay content, which favored water adsorption. The lowest maize height (Table 4) were found in T3 and T4 in DRL, and also in ERL (with T2 similar to T3). This indicates that the plants in soils with additional compaction had limited grow.

The maize yield response in ERL was not affected by the correlation between $S$-index and macroporosity in T4. According to Moncada et al. (2015), there was no direct relationship between high or low $S$-index with grain production, in temperate and tropical soils of medium texture with good condition or limited conditions, respectively. These authors reported that the proposal of a critical reference $S$-index is not generally valid nor even applicable for all soil classes.

According to Lier (2012), the use of $S$-index as an indicator of soil structural quality needs caution, since in absolute terms it does not determine the soil physical quality. This result was also found by Rossetti, Centurion and Sousa Neto (2013). Anghinoni, Carvalho and Costa (2013) found that the tools currently used to evaluate soil physical quality are insufficient for soils under agricultural processes. According to Lima et al. (2014), the $S$-index can be used as a complementary parameter for the soil morphological description in the field.

The finding of Silva et al. (2012) that the $S$ index is a good diagnostic tool to evaluate soil structural quality, must be analyzed under specific criteria; as well as the reports of Cavalieri et al. (2011), who indicated the use of $S$-index for soil physical quality evaluation base on similar results of $S$-index to other established index, the optimal water range. Even in view of the uncertain efficiency of the $S$-index, Yang et al. (2015) considered it as an indicator of soil physical quality. They found a mean $S$-index of 0.77 in the northern China basin and classified it as indicative of good soil quality. From the Lier (2014), research efforts in soil physics should shift towards the mechanistic soil physics, to the detriment of the search for empirical correlations such as $S$-index, which currently represents much more than it should in the soil physics of in Brazil.

According to Table 5, the macroporosity and maize height in DRL are possible parameters to be used together with the $S$-index to evaluate soil quality.

Table 5. Multiple regression analysis of the dependent variable: $S$-index of a Dystrophic Red Latosol (DRL) and an Eutrophic Red Latosol (ERL) subjected to different traffic intensities $(\mathrm{N}=60)$.

\begin{tabular}{|c|c|c|c|c|c|c|}
\hline DRL & $\beta$ & Standard error of $\beta$ & $\mathrm{B}$ & Standard error of B & $\operatorname{Mg}(54)$ & $p$ level \\
\hline Intercept & & & -0.068 & 0.035 & -1.918 & $0.060^{\mathrm{ns}}$ \\
\hline Macroporosity ${ }^{(\mathrm{B})}$ & 0.288 & 0.137 & 0.079 & 0.038 & 2.097 & $0.040^{*}$ \\
\hline Microporosity & 0.028 & 0.104 & 0.030 & 0.109 & 0.276 & $0.782^{\mathrm{ns}}$ \\
\hline Soil Density & -0.152 & 0.165 & -0.014 & 0.015 & -0.923 & $0.359^{\text {ns }}$ \\
\hline Maize Yield & -0.063 & 0.147 & -0.001 & 0.002 & -0.432 & $0.667^{\mathrm{ns}}$ \\
\hline Maize Height & 0.540 & 0.163 & 0.057 & 0.017 & 3.305 & $0.001^{* *}$ \\
\hline ERL & $\beta$ & Standard error of $\beta$ & $\mathrm{B}$ & Standard error of B & $\operatorname{Mg}(54)$ & $p$ level \\
\hline Intercept & & & -0.006 & 0.035 & -0.190 & $0.849^{\text {ns }}$ \\
\hline Macroporosity ${ }^{(\mathrm{B})}$ & 0.120 & 0.172 & 0.036 & 0.051 & 0.697 & $0.488^{\mathrm{ns}}$ \\
\hline Microporosity & 0.082 & 0.131 & 0.026 & 0.041 & 0.629 & $0.531^{\mathrm{ns}}$ \\
\hline Soil Density & -0.058 & 0.174 & -0.004 & 0.014 & -0.335 & $0.738^{\text {ns }}$ \\
\hline Maize Yield & -0.205 & 0.348 & -0.002 & 0.005 & -0.587 & $0.559^{\mathrm{ns}}$ \\
\hline Maize Height & 0.656 & 0.384 & 0.033 & 0.019 & 1.706 & $0.093^{\text {ns }}$ \\
\hline
\end{tabular}

DRL: $\mathrm{r}=0.792 ; \mathrm{R}^{2}=0.628 ; \mathrm{R}^{2}$ adjusted $=0.594 ; \mathrm{F}(5.54)=18.29 ; p<0.000 ;$ Estimated standard error $=0.009$.

ERL: $\mathrm{r}=0.568 ; \mathrm{R}^{2}=0.333 ; \mathrm{R}^{2}$ adjusted $=0.261 ; \mathrm{F}(5.54)=5.168 ; p<0.0006$; Estimated standard error $=0.012$.

$\mathrm{Ns}=$ not significant; $*=$ significant $(p<0.05)$, and $* *=$ significant $(p<0.01)$.

No parameter of the soil or maize plant is useful for analyzing soil quality together with the $S$-index in the ERL. Therefore, for the choice of complementary parameters to $S$-index to compose a set of soil quality indicators it is recommended to consider specific characteristics, such as mineralogy, texture and OM content in this soil class.

\section{CONCLUSIONS}

The $S$-index can not be used as an indicator of structural quality for Eutroferric Red Latosol.

The $S$-index can be applied in the evaluation of soil structural quality as a complementary parameter to maize height and macroporosity in Dystrophic Red Latosol grown with maize, after 
traffic-induced compaction by agricultural machinery.

\section{ACKNOWNLEDGEMENTS}

The authors thank the Coordination for the Improvement of Higher Education Personnel (CAPES) for granting a scholarship to the first author.

\section{REFERENCES}

ANDRADE, R. S.; STONE, L. Índice S como indicador da qualidade física de solos do cerrado brasileiro. Revista Brasileira de Engenharia Agrícola e Ambiental, Campina Grande, v. 13, n. 4, p. 382-388, 2009.

ANGHINONI, I.; CARVALHO, P. C. F.; COSTA, S. E. V. G. A. Abordagem sistêmica do solo em sistemas integrados de produção agrícola e pecuária no subtrópico brasileiro. In: ARAÚJO A. P.; ALVES B. J. R. (Eds.). Tópicos em Ciência do Solo. Viçosa: Sociedade Brasileira de Ciência do Solo, 2013. v. 8, cap. 8, p. 325-380.

ARAÚJO, E. M. Sorção e dessorção de cádmio e chumbo em solos da Bacia do Cabo. 2014. $66 \mathrm{f}$. Dissertação (Mestrado em Agronomia: Área de Concentração em Ciência do Solo) - Universidade Federal Rural de Pernambuco, Recife, 2014.

BERGAMIN, A. C. et al. Compactação de um Latossolo Vermelho distroférrico e suas relações com o crescimento radicular do milho. Revista Brasileira de Ciência do Solo, Viçosa, v. 34, n. 3, p. 681-691, 2010.

BETIOLI JÚNIOR, E. et al. Intervalo hídrico ótimo e grau de compactação de um Latossolo Vermelho após 30 anos sob plantio direto. Revista Brasileira de Ciência do Solo, Viçosa, v. 36, n. 3, p. 971-982, 2012.

BEUTLER, N. A. et al. Densidade do solo relativa e parâmetro "S" como indicadores da qualidade física para culturas anuais. Revista de Biologia e Ciência da Terra, Sergipe, v. 8, n. 2, p. 27-36, 2008.

CAVALIERI, K. M. V. et al. Qualidade física de três solos sob colheita mecanizada de cana-de-açúcar. Revista Brasileira de Ciência do Solo, Viçosa, v. 35, n. 5, p. 1541-1549, 2011.

CUNHA, E. Q. et al. Sistemas de preparo do solo e culturas de cobertura na produção orgânica de feijão e milho. I-Atributos físicos do solo. Revista Brasileira de Ciência do Solo, Viçosa, v. 35, n. 2, p.
589-602, 2011

CUNHA, E. Q. et al. Atributos físicos, químicos e biológicos de solo sob produção orgânica impactados por sistemas de cultivo. Revista Brasileira de Engenharia Agrícola e Ambiental, Campina Grande, v. 6, n. 1, p. 56-63, 2012.

DANE, J. H.; HOPMANS, J. W. Pressure plate extractor. In: DANE, J. H.; TOPP, C. (Eds.). Methods of soil analysis: physical methods. Madison: Soil Science Society America, 2002. p. 688-690.

DEXTER, A. R. Soil physical quality: Part I. Theory. Effects of soil texture, density, and organic matter, effects on root growth. Geoderma, Amsterdam, v. 120. n. 3-4, p. 201-214, 2004.

DEXTER, A. R. et al. A user-friendly water retention function that takes account of the textural and structural pore spaces in soil. Geoderma, Amsterdam, v. 143, n. 3-4, p. 243-253, 2008.

DOURADO NETO, D. et al. Programa para confecção da curva de retenção de água no solo, modelo van Genuchten. Soil water retention curve, SWRC (version 3.0 beta). Piracicaba: USP, 2001. Disponível em: <http://www.esalq.usp.br/ departamentos/lpv/soft.htm>. Acesso em: 05 jul. 2012.

EMPRESA BRASILEIRA DE PESQUISA AGROPECUÁRIA - EMBRAPA. Manual de métodos de análises de solo. 2 . ed. rev. Rio de Janeiro: Embrapa Solos, 2011. 230 p. Disponível em: $<$ http://www.cnps.embrapa.br/publicacoes/>. Acesso em: 01 set. 2015

FLINT, L. E.; FLINT, A. L. Porosity. In: DANE, J. H.; TOPP, G. C. (Eds.). Methods of soil analysis: Physical methods. Madison: Soil Science Society America, 2002. Part. 4, p. 241-253.

FREDDI, O. S. et al. Compactação do solo e produção de cultivares de milho em Latossolo Vermelho. I- Características de planta, solo e índice S. Revista Brasileira de Ciência do Solo, Viçosa, v. 33, n. 4, p. 793-803, 2009.

GROSSMAN, R. B.; REINSCH, T. G. The solid phase, bulk density and linear extensibility. In: DANE, J. H.; TOPP, G. C. (Eds.). Methods of soil analysis: Physical methods. Madison: Soil Science Society America, 2002. Part. 4, p. 201-228.

GUEDES, S. E. M. et al. Impacts of different management systems on the physical quality of an Amazonian Oxisol. Revista Brasileira de Ciência do Solo, Viçosa, v. 36, n. 4, p. 1269-1277, 2012. 
LIER, Q. J. VAN. Índice " $\mathrm{S}$ ": um indicador da qualidade física do solo? Boletim Informativo, Viçosa, v. 37, n. 3, p. 24-27. 2012.

LIER, Q. J. VAN. Revisiting the S-index for soil physical quality and its use in Brazil. Revista Brasileira de Ciência do Solo, Viçosa, v. 38, n. 1, p. 1-10. 2014.

LIMA, H. V. et al. Index of soil physical quality of hardsetting soils on the Brazilian coast. Revista Brasileira de Ciência do Solo, Viçosa, v. 38, n. 6, p. 1722-1730. 2014.

MONCADA, M. P. et al. Evaluation of soil physical quality index $\mathrm{S}$ for some Tropical and Temperate medium-textured soils. Soil Science Society of America Journal, Madison, v. 79, n. 1, p. 9-19, 2015.

REICHERT, J. M. et al. I. Reference bulk density and critical degree-of-compactness for no-till crop production in subtropical highly weathered soils. Soil and Tillage Research, Amsterdam, v. 102, n. 2, p. 242-254, 2009.

ROSSETTI, K. V.; CENTURION, J. F.; SOUSA NETO, E. L. Physical quality of an Oxisol after different periods of management systems. Revista Brasileira de Ciência do Solo, Viçosa, v. 37, n. 6, p. 1522-1534, 2013.

SANTOS, H. G. et al. Sistema Brasileiro de Classificação de Solos. 3. ed. Brasília, DF: Embrapa, 2013. 353 p.

SERVADIO, P. et al. Effects on some soil qualities in Central Italy following the passage of four wheel drive tractor fitted with single and dual tires. Soil and Tillage Research, Amsterdam, v. 84, n. 1, p. 87 -100.2005 .

SILVA, B. M. et al. Índice $\mathrm{S}$ no diagnóstico da qualidade estrutural de Latossolo muito argiloso sob manejo intensivo. Bioscience Journal, Campinas, v. 28 , n. 3, p. 338-345, 2012.

SOUZA, F. R. Influência da intensidade do tráfego e de sistemas de manejo nas propriedades físicas do solo e nas culturas de soja e girassol. 2012. 85 f. Dissertação (Tese em Agronomia: Área de Concentração em Produção Vegetal) Universidade Federal da Grande Dourados, Dourados, 2012.

VAN GENUCHTEN, M. T. A. A closed-form equation for predicting the hydraulic conductivity of unsaturated soils. Soil Science Society of America Journal, Madison, v. 44, n. 1, p. 892-897, 1980.
VAN RAIJ, B. et al. Análise química para avaliação da fertilidade de solos tropicais. Campinas, SP: Instituto Agronômico, 2001. 285 p.

YANG, D. et al. Quantitative assessment of soil physical quality in Northern China based on Stheory. Revista Brasileira de Ciência do Solo, Viçosa, v. 39, n. 5, p. 1311-1321, 2015. 